\title{
TEACHING READING COMPREHENSION DESCRIPTIVE TEXT BY USING PRE- QUESTIONING TECHNIQUE TO THE THIRD SEMESTER OF ENGLISH EDUCATION DEPARTMENT AT UNIVERSITAS ISLAM LAMONGAN
}

\author{
Riya Risqi Setyaningrum \\ riyarisqi@gmail.com \\ FKIP, Universitas Islam Lamongan,
}

\begin{abstract}
One of the important skills that should be mastered in foreign language is reading. In teaching reading activity in the classroom, sometimes students get difficulty in comprehending the text. They could not comprehend the text well that is caused by some factor. One of the factors is lack of information. Pre-questioning is one of the techniques in teaching reading which can give an interaction between the teacher and the students to read the text. The purpose of pre-questioning is to build students' interest and motivation. This study was conducted by the implementation of pre-questioning technique to teach reading comprehension descriptive text. The population was the students' of English Education Department at Universitas Islam Lamongan. The sample was the students of first semester. The class consisted of 30 students. Pre-questioning technique used some tests; each test was different items of questions. The data was taken by observation checklist and tests. The measure of the students' achievement was stated by Harris (1969:134). The data have got from the result of pre-test, formative test1, formative test 2 and post-test. It found that post-test is higher than pre-test and formative test. The percentages were added from pre-test $56.67 \%$ to post-test $80 \%$. In conclusion, pre-questioning gives the contribution towards students' reading comprehension ability. After conducting the study, the researcher suggests that in teaching reading, the English teacher should build a favorable atmosphere at times of teachinglearning process conducted, because a conductive condition in teaching would become one way to carry out the material to be taught and improve the students' interest and motivation in learning English, especially in reading skill.
\end{abstract}

Key words: Reading Comprehension, Teaching Reading, Pre-Questioning Technique, Descriptive Text

\section{INTRODUCTION}

Language is a tool of communication that is used among people around the world. English has become an international language of spoken and written communication. It has an important role in globalization era when it is used as a language science, technology, art, education, politics, commerce, economy, international relationship, etc. Language is not only considered in terms of its structure but also in terms of communicative function that it performs (Littlewood, 1981, p. 10)

In English, there are four skills that should be mastered. They are listening, speaking, reading and writing. Reading is one of the important skill in the education field. Students need to be exercised and trained in order to have a good reading skill. Based on this phenomenon, it was necessary for the teacher to build communication with the students. PreQuestioning can be one of the technique in building communication between teacher and students. It stimulates how well it is adapted to the ability and experience of the pupils and what extent in encouraging complete though. Theoretically, prequestioning itself can build the student's interest and motivation before reading the whole text. A question may be judge on the amount of reflection (Harley \& Shipley, 1967, p. 46).

Based on the preliminary study, the research conducted in first semester of English Education Department at Unisla on October $8^{\text {th }}, 2018$ the researcher found that the students' skill in reading comprehension was poor. Every reading activity their score maximum was 55 on a $0-100$ scale. The class is categorized 
successful if the mean score is 75 . It means that the class did not reach the criteria of success.

Based on the explanation above, the researcher is interested in conducting a research to describe teaching reading comprehension of descriptive text by using pre-questioning technique. The researcher used pre-questioning technique to build students' interest and motivate them to improve their reading ability.

\section{Reading Comprehension}

Many people assume that reading is an activity of looking at and understanding written form. While reading are different definitions based on different people. Reading is a process of decoding written symbols, working from smaller units (individual letters) to large ones (words, clauses, and sentences) (Nunan, 1989, p. 17). Reading comprehension is important, not just understanding text, but for broader learning, success in education, and employment (oakhill, Cain, \& Elbro, 2015, p. 1). It means that reading comprehension is a complex task, which requires the orchestration of many different cognitive skills and abilities.

The basic reading comprehension skill that can reasonably be expected in a school are (Tay, 1979, p. 7). The ability to recognize that main idea of reading election are:

a. The ability to note details

b. The ability to summarize and recognize the ideas

c. The ability to follow the sequence of ideas

d. The ability to predict and anticipate outcomes

\section{Types of Reading}

There are two types of reading (Harras, Kholid, \& Sulistianingsih, 1998, p. 13). First is Intensive Reading. Intensive reading here means an activity of reading in class where the student read passage with help by the teacher. In this reading activity, the role of teacher as a guide to bring the student to be efficient and skillful reader is very obvious. The major objective of intensive reading is developing the students' ability to decode message by drawing on syntactic and lexical cues, and it also emphasizes in skill for recognition. Second is Extensive Reading. Extensive reading here means that the reader read a text without an emphasis on analysis of word and grammatical points. Although such reading is meant as independent reading, there should be regular and systematic feedback from it.

\section{Teaching Reading}

In teaching English, reading skill is an ability that cannot be neglected at all. Mastering reading skill is regarded very important to be taught because it will influence other skills of English (such as; listening, speaking and writing). Reading without comprehension or understanding is not reading. Sometimes many students can pronoun words fluently but when they asked about what they have just read, they are unable to respond. The aim of teaching reading is to make students able to comprehend the reading text and steps to develop the rhetoric in written text (Nasional, 2003, p. 20). So the students should competence in comprehension.

There are some steps that should be considered to improve reading comprehension (Miller, 1990, p. 7). They are:

a. Attention is an absolute perquisite to intensive mental impressions

b. Interest is the power to give a lot of attention in the content of reading

c. Purpose contributes greatly to amount of attention long enough to establish the vivid impressions which contribute o much to recall abilities.

This study concludes that prequestioning as the strategy to build up and 
to raise the students' skill in predicting what will be faced by them for the whole text. Especially, this technique could improve the students' interest and motivation in reading activity. Prequestioning encourages the students to learn how to answer questions better. Students are asked to indicated whether the information they used to answer the questions about the text was textually explicit information (information that was implied in the text), or information entirely from the student's background knowledge.

\section{The Activity of Reading}

The purpose in teaching reading is to develop the students' skill especially in reading comprehension that they can read English text effectively and efficiently. There are three kinds of activities in relation to reading classroom activities (Gerry \& Wingard, 1981, p. 95)

a. Pre-reading activity

The overriding aim in doing any classes work without learners before. They began to read a text is to create a positive attitude in their minds towards the text to be read.

The activities including in prereading (Abbot, 1981, p. 95): Finding out with the students already know about the subject, Asking the students to read only the text and then say or write down what they expect the text to be out., Showing the picture to recall the students' description about the text they are going to have, and Giving some or all the unknown vocabulary as keyword whose meaning is crucial to understand the text.

\section{b. Whilst-reading activity}

This activity requires the teacher's guidance to ensure that students assume an active questioning approach to the material. The types of reading activity depend on the student's reading and comprehension skill and their experience with expository reading. Concerning with the explanation above, Abbot describes the activities involves in the whilst-reading activity, they are: identifying the main idea, finding details in text, following a sequence, inferring from the text, recognition the writer' purpose and attitude, recognition the discourse features, and the teacher's role is help the both individual learner with their particular difficulties and their whole group.

c. Post-reading activity

The goals are post-reading activities to integrate, synthesis, and consolidate the information that has been read in the selection. There are some activities postreading activities, they are: Filling in the blank concept map, discussing content in the class notes, and developing a visual representation of the information.

\section{Pre-Questioning Technique}

Pre-questioning implicitly some questions are provided before the student read the whole text, in order to build students' interest and motivation in reading activity (Brown, 2001). Furthermore, their cognitive factors and pre-questioning are very useful to activate the schemata. Pre-questioning can be effective for students because it gives student a purpose of reading, focus student's attention on what they are learn, help students to think actively as they read, encourage students to monitor their comprehension and help student to review content and relate what they have learned to what they already know.

\section{Kinds of Pre-Questioning}

There are four kinds of prequestioning (Harmer, 1985, p. 153), they are:
1. Pre-questioning before reading to confirm expectation

Pre-questioning is used as a tool for motivating students on lead -in stage (where students are encourage to 
become interested in the subject matter of the text), encourages students to predict the content of the text, and give them an interested and motivating purpose for reading.

2. Pre-questioning before reading to extract specific information

Pre-questioning is used as a tool to force the students to extract specific information from the text. They are going to answer before reading the whole text. If they do this, it will be possible for them to read in the required way, they should see the text only to extract the information of the questions demand. Pre-questioning before reading for general comprehension

3. Pre-questioning before reading for general comprehension

Pre-questioning is used to build up the student's prior knowledge

4. Pre-questioning before reading for detailed comprehension

Pre-questioning intends to give the students some detailed information that should be found by them in the whole text.

Based on the explanation above, the writer only focuses in two kinds of prequestioning. They are pre-questioning before reading for general comprehension and pre-questioning before reading to confirm expectation.

\section{Descriptive Text}

A paragraph is a group of related sentences about a single topic (Hogue, 1996, p. 3). A paragraph has a topic sentence, supporting sentence and concluding sentence. The kinds of paragraphs can be based on the content of the paragraph itself. The content of the paragraph will influence the information and the organization of the paragraph.

In this study, the researcher used pre-questioning technique to teach reading comprehension. It used to improve students' understanding in reading comprehension of descriptive text. Teaching and learning process is emphasized on the achievement of the standard competence, that is the students are able to communicate orally or reading comprehension by using appropriate types of language fluently and accurately in the interaction or monologue which covers description, anecdote, narration, argumentation, persuasion, report, news item, discussion, procedure and review text.

\section{Action Research}

This part presents the general concept of action research, and characteristics of action research.

\section{General Concept of Action Research}

When conducting research, especially in educational research, I need a specific strategy by reviewing the previous strategy done by expert and try to conduct the study used those strategies so that is it will reliable. A form of research, which is becoming increasingly significant in language education, the characteristics of action research are firstly, it is carried out by practitioners (for our purpose, classroom teacher) rather than outside researcher. Secondly, it is collaborated. Thirdly, it is aimed changing things (Nunan, 2003, p. 17)

Action research is an inquiry or research in the context of focused efforts to improve the quality of an organization and its performance. It typically is designed and conducted by practitioner who analyzes the data to improve their own practice. Action research can be done individuals or by teams of colleagues. The team approach is called collaborative inquiry.

It means that action research is an action in a research, which can be done by teacher, researcher, and the teacher with his/her colleague. This involves a group of students to improve learning and teaching- 
learning process or to enhance the students' understanding of the lesson. Action research methodology offers a systemic approach to introducing innovation in teaching and learning. It seeks to do this by putting the teacher in the dual role of procedure of educational theory, and user of that theory. This is both of a way of producing knowledge about higher education learning and teaching, and a powerful way in improving learning and teaching practice.

Mattetal(www.scu.edu.au/schools/g cm/ar/ari/plywadsworth98.htm $)(03 / 03 / 201$

5) gives differences between formal and action research. In Table 21

Table 2.1 The Differences between Formal and Action research

\begin{tabular}{|c|c|c|}
\hline Topic & Formal research & Action Research \\
\hline Sampling Approach & Random and representative sampling & $\begin{array}{l}\text { Students or client with whom they } \\
\text { work }\end{array}$ \\
\hline
\end{tabular}

$\begin{array}{ll}\text { Emphasis on theoretical significance; } \\ \text { Application of result } & \begin{array}{l}\text { Emphasis on practical significance; } \\ \text { increase knowledge about teaching and } \\ \text { learning general }\end{array} \\ \text { particular classroom. }\end{array}$

Based on the table above, it is clear that the teacher can choose students as the sampling. Moreover, it is improves teaching and learning in particular classroom

\section{Characteristics of Action Research}

Action research has several characteristics which will be elaborated that follows; First, On the Job Problem Oriented. Problem which is being investigated appears from the authority of the researcher herself. The problem is the real problem faced by the researcher every day. Second, Problem Solving Oriented. The research is oriented on the problem solving. This short of research put of researcher as the agent of change. Third, Improvement Oriented. This research gives emphasis on the improvement of quality. This concept is according to the principal of critical research has to construct oriented. Fourth, Multiple Data Collection. In fulfilling the critical approaches principle, there are several ways of collecting data, such as field notes, test and questionnaire. Fifth, Cycling. The sequence of the action research is planning, acting, observation and reflection. Sixth, Participant. Researcher makes such collaboration with other people to do the action research

METHOD

\section{was qualitative. In conducting the} was qualitative. In conducting the research, researcher used action research that used qualitative approach and observation, which means that the data were analyzed qualitatively. The research design was an action research. There are four phases in one cycle for doing classroom action research. They are planning, implementation, observation and reflection (Nasional, 2003, p. 4). Those four components are integrated. In this action research, researcher conducted two cycles. But before the cycles are carried out, the researcher and conducted a preliminary study to the subjects. Every cycle consisted of four phases. There were; planning, implementation, observation and reflection. In planning, the researcher also divided the steps of activities into three steps. There were; pre-reading activity, whilst-reading activity and post-reading activity. The subject of this research is the students of first semester of English Education Department at Unisla Lamongan.

The researcher assisted by two collaborators discussed about the problem faced by the students at the first semester in academic 2018/2019. The researcher used two methods to collect the data which appropriate to the school environment and the students' condition. They were 
observation checklist, field note and tests. The required data and information will be obtained from two main sources, they are; library research and field research.

\section{Result and Discussion}

The research was conducted at English Education Department of Unisla. The first activity was conducted on October $8^{\text {th }}, 2018$. In this stage, the researcher gave pre-test of reading comprehension of descriptive text. It was intended to know the students' achievement before having some treatment by using pre-questioning technique. The second activity was cycle 1 or treatment 1 . It was conducted on October $15^{\text {th }}$ and $22^{\text {th }}$, 2018. In this activities, the researcher gave exercise that should they do in their group. They should discuss how to implemented pre-questioning technique in reading comprehension of descriptive text. The third activity was cycle 2 or treatment 2 . It was conducted on October $29^{\text {th }}$ and November $5^{\text {th }}$, 2018. In this stage the researcher gave the students some of descriptive text with some questions. On October $29^{\text {th }}, 2018$ the students only learn how to comprehending descriptive text, implemented pre-questioning technique in reading comprehension and understanding every questions of reading test. Meanwhile, on November $5^{\text {th }}, 2018$ the students got test. The forth activity was post-test. It was conducted on November $12^{\text {th }}, 2018$.

The analysis of teaching learning process is obtained based on the information from the observation checklist and field note. The information was about the activities during the implementation of teaching reading comprehension of descriptive text by using pre-questioning technique. Based on the field note, the students made noisy in every meeting. The students opened dictionary when they did not know what the question means is.
Almost 70 percent of them lack in vocabularies.

\section{Analysis of the Results}

For the first step, the researcher did pre-test. It was conducted to check the students' achievement in comprehending descriptive text. It was conducted on October $8^{\text {th }}, 2018$. There were 30 students who followed the test. There were 20 items. It was multiple choices. The student's score $71-80$ were $2,61-70$ were 9 students, 51 - 60 were 10 students and less than 50 were 9 students. It means that the students were not success in comprehending reading descriptive text.

In the cycle 1 , it was done in two meeting. The students were unfamiliar with descriptive text and pre-questioning technique. They never had been learned before. So, the researcher explained descriptive text. The researcher gave some warm-up questions related the material, such as genres, definition of descriptive text, social function, generic structure and generic features of descriptive text and other component of descriptive text. During teaching and learning process of cycle 1, most of students looked enjoy with English. Only a few students made noisy and trouble, they were boys.

The first meeting of cycle 1 presented BKOF (Building Knowledge Of the Field), and MOT (Modeling Of the Text). In the first activity (BKOF), the researcher reviewed the social context of descriptive text by using pre-questioning technique and enriching knowledge about descriptive text. These activities are focus on the implementation of technique in teaching reading comprehension of descriptive text. There were three stages in this activity. There were pre-reading, whilst-reading and post-reading. The researcher guided the students to identify the components of descriptive text. In the second activity (MOT), the researcher reviewed descriptive text. The students 
were trained to gain the important information from the text.

The second activity the students did test. The questions consisted 10 items. It was essay. They did in group who consists of five students. They chose randomly by the researcher. From cycle 1, the researcher knew that the students' achievement by classify the students' score and used formula to find out the percentage. The student's score in cycle 1; $71-80$ were 15 students, $61-70$ were 10 students, and $51-60$ were 15 students. It was 70 percent students who succeeded. It means that the technique almost success.

In the cycle 2 , it was also two meeting. It was conducted on October $29^{\text {th }}$ and $5^{\text {th }}$ 2018. Generally, procedure of teaching and learning activity was same as the previous cycle. The main focus of this treatment was to improve the students' reading comprehension of descriptive text. But in this cycle the students did not doing the activity by group. They did by themselves.

The first meeting was BKOF and MOT. In the term of BKOF, the researcher shows how to comprehending the information of descriptive text. In MOT, the researcher explained how to answer the question by using pre-questioning technique. The procedure of test was also same with test in cycle 1 . From cycle 2,

\begin{tabular}{|c|c|c|c|c|c|}
\hline \multirow{2}{*}{ Criteria of Mastery } & \multicolumn{4}{|c|}{ Frequency } & \multirow[t]{2}{*}{ Level Of Achievement } \\
\hline & $\begin{array}{l}\text { Pre- } \\
\text { Test }\end{array}$ & Cycle 1 & Cycle 2 & Post-Test & \\
\hline $91-100$ & 0 & 0 & 0 & 0 & Excellent \\
\hline $81-90$ & 0 & 0 & 4 & 15 & Very Good \\
\hline $71-80$ & 2 & 15 & 16 & 12 & Good \\
\hline $61-70$ & 9 & 10 & 3 & 2 & Fair \\
\hline $51-60$ & 10 & 15 & 2 & 1 & Poor \\
\hline Less Than 50 & 9 & 0 & 5 & 0 & Very Poor \\
\hline
\end{tabular}

the researcher known the student's achievement was advance. The student's score, $81-90$ were 4 students, $71-80$ were 16 students, $61-70$ were 3 students, $51-60$ were 2 students, and less than 50 were 5 students. It was 71 percent of students who were success. It means that the technique was more success than before. Although, there were 5 students who got score less than 50 .

The last was post-test. It was last step to know the students' achievement in comprehending reading descriptive text by pre-questioning technique. It was conducted on November $12^{\text {th }}, 2018$. The procedure of post-test was same in pretest. From post-test, the researcher known the student's achievement in comprehending reading descriptive text increased. The students' score, $81-90$ were 15 students, $71-80$ were 12 students, 61 - 70 were 2 students, and 51 60 were 1 student. It means that there was no student who got score less than 50 . The percentage of students' achievement in post-test was higher than pre-test. It was 80 percent students who succeeded. In understanding more of this research, check this classification of students test and the percentages. 


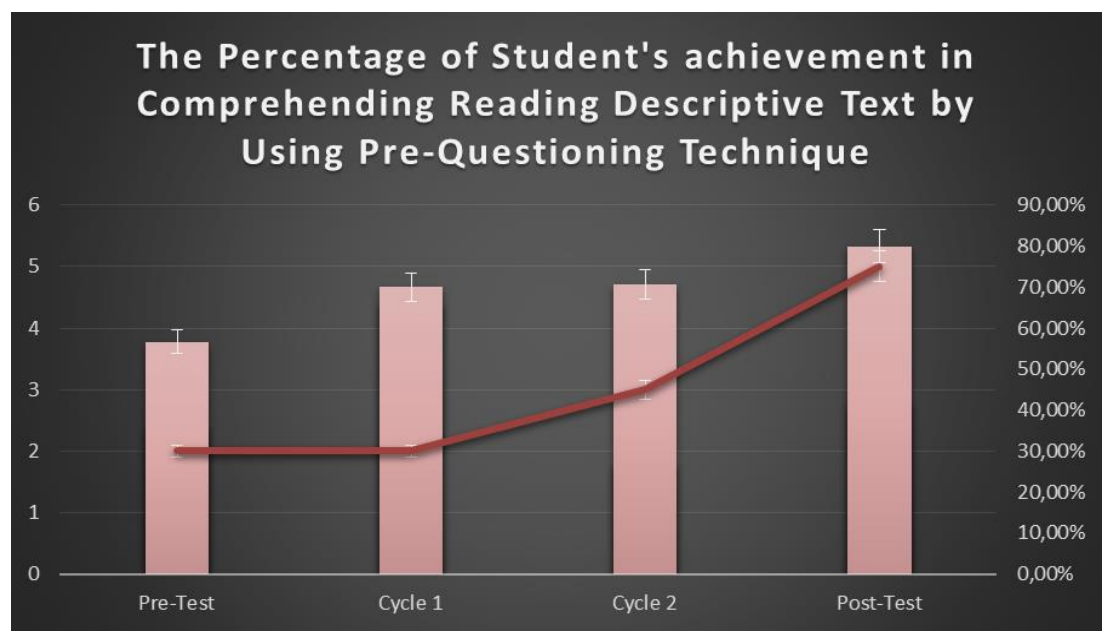

The Result of Observation Checklist, Field Note, and Test

The objective of this research was to describe the implementation of teaching reading comprehension of descriptive text to the First semester of English Education Department at Universitas Islam Lamongan in the academic years of 2018 / 2019 and to describe students' behavior change during the treatments.

The observation shown that students' behavior change from pre-test up to the last test, it was post-test. It was show from student's score. The field note was shown the improvement of student's activity. Their attentions in teaching learning activity were improved. Question answer happened in the third meeting until the end of meeting. They were not only improving their attention, but also their score were improved. This research showed that there was positive effect in teaching reading comprehension of descriptive text by using pre-questioning technique. It could improve students' interest and motivation in learning English, especially in reading skill.

\section{Discussion}

The discussion of the research was focused on the result of the activity in teaching reading comprehension of descriptive text by using pre-questioning technique in every activity. Student's ability in comprehending reading descriptive text was the most important thing in this research. Based on the finding, this technique could improve the student's ability and motivate them in learning reading comprehension.

Firstly, the researcher gave them pre-test to measure the students' ability in comprehending reading descriptive text. The student's score in this stage was very low and they were poor in understanding what descriptive text is. It caused they never learn English before at elementary school. After known the student's ability, the researcher prepared the treatment by using pre-questioning technique. It has treatment 1 (cycle1) and treatment 2 (cycle2). In those activities, there were BKOF, MOT, JOT, and COT. The researcher gave them model of task of descriptive text. Then the researcher explained the social function, generic structure and generic feature of descriptive text. The researcher helped them to analyze the content of descriptive text based on the text which was given. The last, the researcher asked the students to comprehending reading descriptive text in group that was divide by researcher.

The result of the treatment shown that a cycle 2 activity was higher than cycle 1 . The final score in post-test was higher that pre-test. The researcher realized that not all of teaching and learning activity could run well. Some of students seemed understand well with the 
p-ISSN: 2085-1383; e-ISSN: 2621-4156

explanation but some of them did not. It was common problem in class. It caused not all students had enthusiasm in learning English. The problem might rise by the student's lack in vocabulary. It means that pre-questioning technique was success to improving student's interest and motivation in learning English ability, especially in reading comprehension.

\section{CONCLUSION}

Conclusion answered the problem presented in background of study. The whole description and result of analysis leads the researcher to draw the following conclusion. First, the implementation of teaching reading comprehension of descriptive text by using pre-questioning technique was good. They were interested and motivated in learning reading comprehension by this technique. Second, the technique was very useful improve the student's ability in comprehending reading descriptive text. As the percentage of the result, the student's progress during the treatment was good enough. It increased from pre-test 56.67 percent to post-test 80 percent. The technique could help them to comprehend the text easily. They also improved their vocabulary acquisition.

\section{REFERENCES}

Abbot, Gerry. (1981). Comprehension and Reading: In Teaching of English As International Language, A Practical Guide. Glasow: William Cilon Son.

Brown, H Douglas. (2001). Teaching by principles. New York: Pearson Education.

Harley, Barry, \& Shipley, C Morton. (1967). A synthesis of teaching methods: McGraw-Hill.
Harmer, Jeremy. (1985). The Practice of English Language Teaching. England Pearson Education.

Harras, Kholid, \& Sulistianingsih, Lilis. (1998). Materi Pokok Membaca 1. Indonesia: Departemen Pendidikan dan Kebudayaan.

Hogue, Ann. (1996). First steps in academic writing (Vol. 1): Longman Publishing Group.

Littlewood, William. (1981). Communicative language teaching: An introduction: Cambridge University Press.

Miller, Wanda M. (1990). Reading faster and understanding more (Vol. 2): Addison-Wesley Longman.

Nasional, Departemen Pendidikan. (2003). Kurikulum 2004: Standar kompetensi mata pelajaran bahasa Inggris sekolah menengah atas dan madrasah aliyah: Jakarta: Depdiknas.

Nunan, David. (1989). Designing tasks for the communicative classroom: Cambridge University Press.

Nunan, David. (2003). Practical English language teaching: McGrawHill/Contemporary.

oakhill, Jane, Cain, Kate, \& Elbro, Carsten. (2015). Understanding And Teaching Reading Comprehension; A handbook. New York: Routledge.

Tay, Mary W.J. (1979). Teaching Readdinng Comprehension: A 'skill' ApproachGuidline For Teaching Reading Skill. Singapore. 